\title{
Norske leger i Kongo 1885-1908
}

\begin{abstract}
Sammendrag
Kongofristaten som ble opprettet i 1885 under Leopold 2.s formynderskap, ble hans private koloni. I 1908 ble kolonien, etter utenlandsk press, overtatt av den belgiske staten på grunn av kongens vanstyre. Til koloniseringen rekrutterte kongen mange fra land utenom Belgia. Fem norske leger tok tjeneste i fristaten. To måtte reise hjem etter et års tid på grunn av malaria, mens én gjennomførte tre års kontraktstid uten å være syk en eneste dag. Mest kjent ble Inge Heiberg (1861-1920) og Johan Cammermeyer (1872-1949). En sovesykeepidemi herjet fristaten i årene 1896-1906, og begge engasjerte seg i bekjempelsen av den.
\end{abstract}

\section{Aksel Ongre \\ aksongr@online.no \\ His}

Ved en internasjonal diplomatisk konferanse i Berlin i 1884-85, der Belgia ikke deltok, ble Kongofristaten (État Indépendant du Congo) etablert under kong Leopold 2.s (1835-1909) formynderskap. Frihandel, avskaffelse av slavehandel, misjonsvirksomhet og utforskning var foringer for utviklingen av dette store, sentralafrikanske landet. I virkeligheten ble fristaten kongens private koloni og handelsforetak. Til koloniseringen rekrutterte han også skandinaver. Det ble en skjebnetung innsats i Afrikas hjerte, som det har vært nokså stille om (1). Men i de senere årene har omskrivning av kolonihistorien ført til ny interesse for Kongofristaten $(2,3,4,5)$.

Over 200 nordmenn tjenestegjorde i kolonien. Den største gruppen var sjøfolk, den nest største militære offiserer. Men også jurister, leger og andre dro til Kongo. De ble ansatt for tre år om gangen av Kongofristaten eller handelskompanier. På en liste over 187 norske kongofarere finner man fem som virket som leger (6).

Det har i de senere årene vært en del interesse for Norges bidrag til kolonialisme. I den forbindelse kom jeg til å skrive en artikkel i Bjarkøy historielags årbok 2010 om min mormors fettere som tjenestegjorde som sekondløytnanter i leiehæren Force Publique i Kongo (7). Arbeidet med den artikkelen vekket interessen for legene som dro dit.

Denne artikkelen skal handle om disse legene, om hvorfor de dro, og hva de opplevde der nede. For å finne informasjon har jeg kontaktet Afrika-arkivet i det belgiske utenriksdepartementet, Institute of Tropical Medicine Antwerpen, Liverpool School of Tropical Medicine, Bernhard-Nocht-Institut für Tropenmedizin Hamburg, Royal Society of Tropical Medicine and Hygiene London, Musée McCord Museum i Montreal og The Wellcome Trust i London.

\section{Legene og deres faglige bakgrunn}

Peter Munch Søegaard (1866-1923)

tok medisinsk eksamen i desember 1891. I 1894 ble han ansatt i Kongofristaten, men etter et års tid måtte han i 1895 reise hjem på grunn av malaria (8).

Inge Valdemar Heiberg (1861-1920) tok medisinsk eksamen i 1893 og ble høsten 1897 ansatt i fristaten Kongo (9). Etter at fristaten i 1908 ble belgisk koloni, ble han i 1911 «Médecin en Chef», og han var den første medisinaldirektøren for Belgisk Kongo, bosatt i Boma. Han ble fra 1903 engasjert i kampen mot sovesyke. Mellom 1903 og 1920 skjenket han flere hundre gjenstander til kongoavdelingen i Etnografisk museum i Kristiania og ble museets største giver noensinne (2). I 1908 ble han ridder av St. Olavs orden, for allmennyttig virksomhet. Han fikk også flere belgiske ordener. Han vendte hjem til Kristiania med sviktende helse i 1920 og døde kort tid etter. På kransen til hans båre skrev Historisk museum: «til den bedste av dets venner.» (10) Han var bror av forfatteren Gunnar Heiberg (1857-1929) og sto, som ham, i 1880-årene Kristiania-bohemen nært. Etter hvert trakk han seg mer tilbake og ble beskrevet som beskjeden og selvkritisk, men elskverdig, hjelpsom, klok og fintfølende (10). Malaria og influensa hadde satt sine spor, og med aortainsuffisiens i tillegg sviktet hjertet. $(9,11,12)$.

Olaf Berge (1868-1915) tok medisinsk eksamen i 1892. I 1898 dro han til Kongo, men måtte reise hjem i 1899 på grunn av «haardnakket klimatfeber, fièvre hematurique». Kort etter hjemkomsten fikk han et residiv «ledsaget af forholdsvis svære leversymptomer» (13).

Johan Widing Heiberg Cammermeyer (1872-1949) tok medisinsk eksamen i 1899. I 1904 dro han til Kongofristaten (14). Etter tre års kontraktstid var han hjemme i 1907. Samme år dro han tilbake til Kongo med stasjon i Boma. I 1919 ble han «Médecin inspecteur provincial», og i 1923 ble han ridder av Den belgiske Løveordenen for sitt virke som sjef for medisinalstyrelsen i Ekvator-provinsen. Han fikk for øvrig flere ordener, blant annet erindringsmedalje for sin virksomhet under krigen 1914-18. Han dro hjem i 1923 og slo seg ned i Kristiania med blod- og tropesykdommer som spesialitet. Han donerte en stor samling etnografika til Historisk museum. Til tollernes fortvilelse hadde han med seg 60 kolli da han kom hjem i 1923 (2).

Jan Haavik (1879-1953) tok medisinsk eksamen i 1906 og dro i 1907 til Kongofristaten der han virket i Uele-distriktet i statens tjeneste i tre år. Om oppholdet i Kongo skrev han: «Jeg gruede for Congo. Til min behagelige overraskelse opdagede jeg straks, at jeg trivedes udmerket dernede i hjertet af «Det mørke fastland», (...) jeg var ikke en dag syg dernede. Jeg tænker endnu paa dette merkelige land. Har af og til lidt «nostalgie d'Afrique.» (15).

De norske legene som dro til Kongofristaten hadde ingen utdannelse i tropesykdommer da de ble ansatt. Da Heiberg returnerte til Kongo 1.5. 1903 over England (16), fulgte han et kurs i tropemedisin ved Liverpool School of Tropical Medicine (17). Skolen ble grunnlagt i 1898 og var den første institusjon som ble opprettet spesielt for tropesykdommer. Heiberg er registrert

\section{Hovedbudskap}

- Fem norske leger tjenestegjorde i Kongofristaten

- To av dem ble engasjert i bekjempelsen av en stor sovesykeepidemi i en tid da man ikke hadde effektiv behandling

- Tvangsundersøkelse og isolasjon ble oppfattet som en del av et undertrykkende regime av afrikanerne

- Nedbryting av sosiale strukturer i lokale samfunn, med tvungen migrering av arbeidskraft, bidro til epidemiens omfang

- Da sovesykeepidemien etter hvert avtok, skyldtes det like mye sosiale forbedringer som medisinske fremskritt 


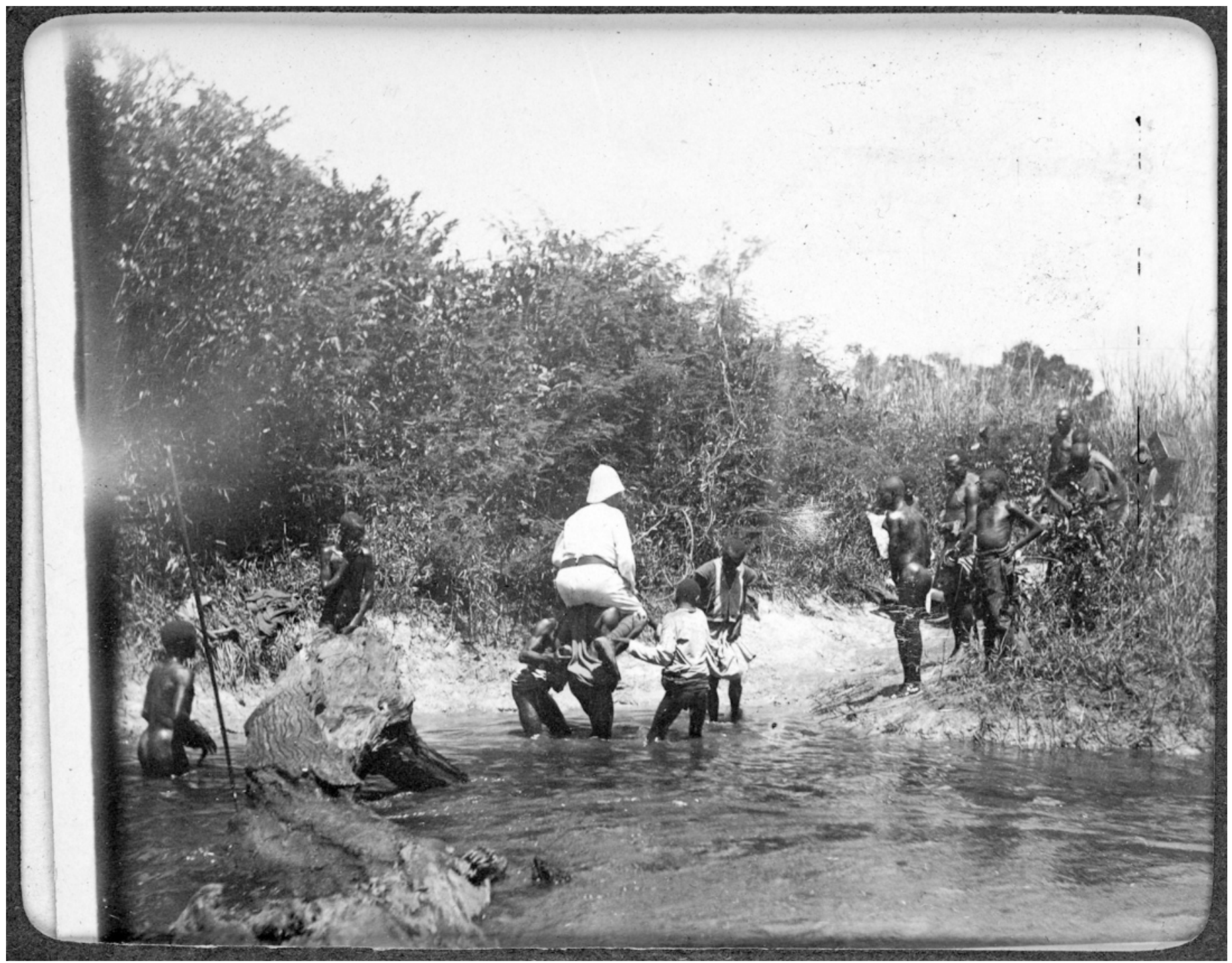

Ekspedisjonen krysser en elv på veien mellom Kasongo og Lusambo. Bildet er trolig fra den 12. trypanosomiasis-ekspedisjonen til Kongo i 1903 arrangert av Liverpool School of Tropical Medicine. Det stammer fra bind fem av i alt sju fotoalbum fra perioden 1902-05. Foto Wellcome Library, Wellcome Images, London

som student nr. 63, regnet fra undervisningen startet i 1899. Den neste institusjonen var Institut für Schiffs- und Tropenkrankheiten i Hamburg, i dag Bernhard-NochtInstitut für Tropemmedizin, som startet sin virksomhet i 1900 med marinelegen Bernhard Nocht (1857-1945) som direktør.

Cammermeyer fulgte kurs i tropemedisin i 1907 ved Ecole de Médecine Tropicale som ble opprettet i Bruxelles i 1906, men senere flyttet til Antwerpen. Haavik, som bare hadde $1 \frac{1 / 2}{2}$ måneds praktisk erfaring etter medisinsk eksamen da han dro til Kongo i 1907, fikk kurs i tropesykdommer i Bruxelles.

\section{Hvorfor dro de til Kongo?}

Man kan undre seg over hva som fikk leger til å reise til Afrika på slutten av 1800tallet. De må ha kjent til den høye dødeligheten og sykeligheten og den risikoen de utsatte seg for. Likevel dro de. Faktorer som penger, arbeidsløshet, misjonærvirksomhet, nysgjerrighet og eventyrlyst kan ha spilt inn (18). Risikoen for å pådra seg tro- pesykdommer med høy dødelighet, eventuelt varig svekkelse av helsen, var nok skremmende, men det var heller ikke ufarlig her hjemme hvor tuberkulosen som herjet, var den største dødsårsaken.

Om kongofarerne som gruppe skriver Kjerland og Bang at de reiste ut fordi de ikke fant seg til rette i Norge - enten fordi de ikke fant arbeid, eller fordi de ønsket seg bort fra vanskelige personlige eller sosiale forhold (19). I Heibergs tilfelle kan kjærlighetssorg ha vært en medvirkende da Bokken Lasson (1871-1970) gjorde slutt på et forhold som hadde vart i sju år $(11,12$, 20). Olaf Berge skriver at det ikke hadde manglet på advarsler da han dro til Kongo (13). Men han ønsket innstendig å få lagt seg opp midler slik at han kunne studere kirurgi et par år i utlandet. I stedet ble det tidlig hjemreise til assistentlegestilling ved «Eg sindsygeasyl».

Da Munch Søegaard i 1905 anmeldte boken Skandinaver i Congo, spurte han hvorfor de unge kongofarerne så freidig «havde gaaet Lidelser og Død imøde der- nede i det mørke Afrika». I festtalene, gravtalene og nekrologene var det for å arbeide i sivilisasjonens og filantropiens navn, men i virkeligheten tjente de bare merkantile interesser som fylte kong Leopolds pengepung (21). Elfenbein og kautsjuk var kongens viktigste inntektskilder, ervervet ved tvangsarbeid som ble pålagt innbyggerne.

\section{Sykdom og død}

Berge forteller at da han reiste hjem i 1899, etter et års opphold, var over halvparten av reiseselskapet på nedturen enten døde eller reist hjem på grunn av sykdom. Det samlede antall skandinaviske kongofarere var 812 fra 1878 til og med 1902, hvorav 100 var norske (22). Av leger var det to svenske, tre danske og tre norske. Av de 100 norske døde 22 i Kongo og to på hjemreisen. I alt 28 personer måtte reise hjem på grunn av sykdom før utløpet av første termin. Av de 812 skandinavene var det 182 som døde i Kongo, og 24 som døde som følge av oppholdet.

Noen dødsårsaksstatistikk har jeg ikke 


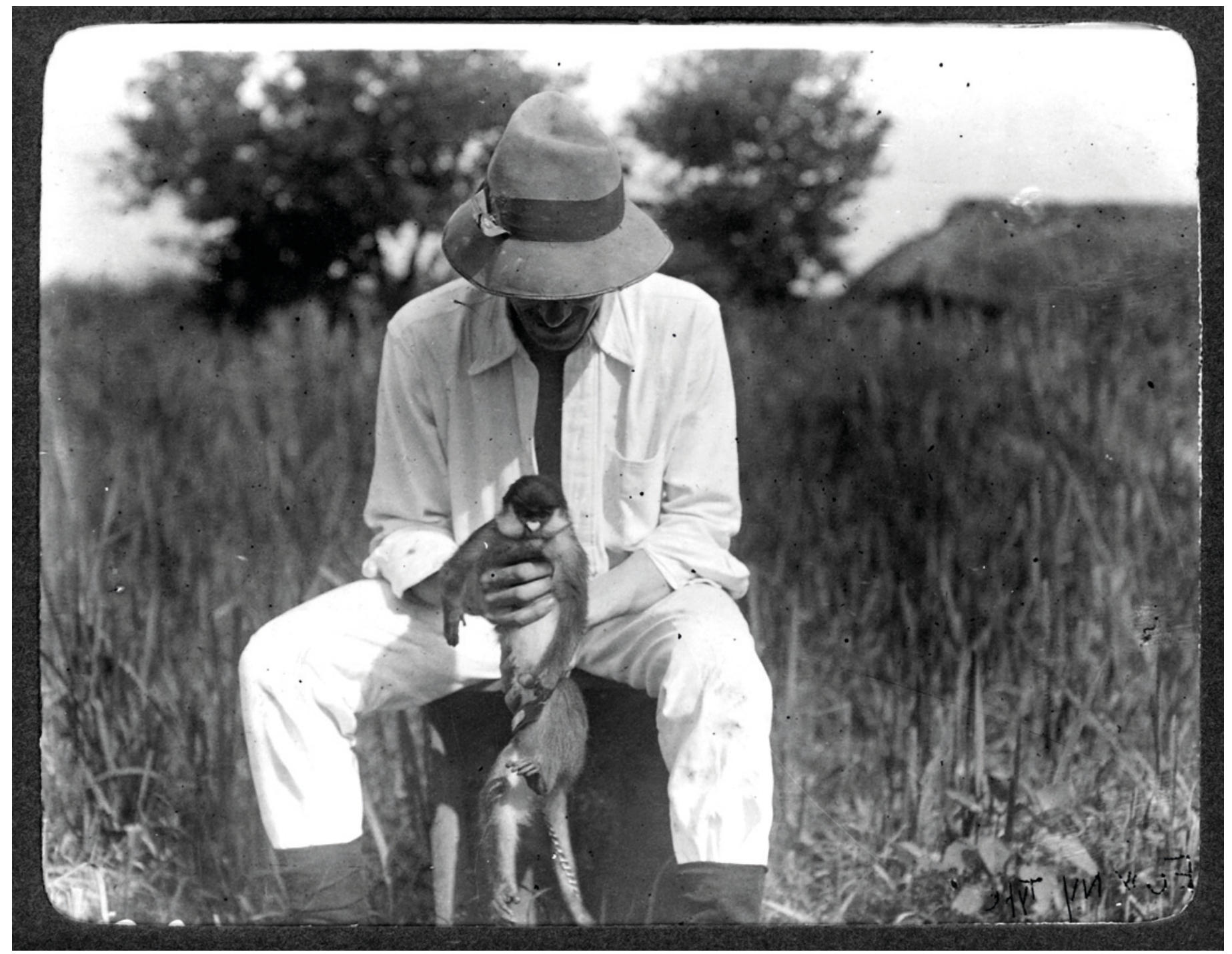

Legen John Lancelot Todd (1876-1949) med en ape som ble brukt i eksperimenter på en ekspedisjon i Kongo 1903-05. Foto Wellcome Library, Wellcome Images, London

funnet. Dette var i en tid da tropesykdommer ble en egen gren av medisinen, hvor man hentet kunnskap fra veterinærmedisin, protozoologi, parasittologi, helmintologi,

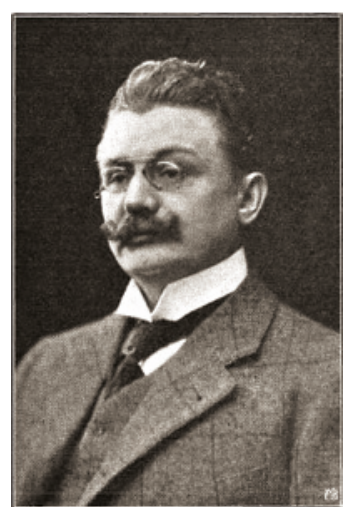

Inge Heiberg (1861-1920) var en stor donator til Etnografisk museum i Kristiania i årene fra 1903 (i dag Kulturhistorisk museum i Oslo). Bilde fra boken Universitetets ethnografiske samlinger 1857-1907: en historisk oversigt over deres tilblivelse, vækst og udvikling av Yngvar Nielsen, utgitt i 1907. Foto Wikimedia Commons entomologi, bakteriologi, hematologi, kjemi og mikroskopi (23). Da man oppdaget at mange av sykdommene som gikk under navnet klimatfeber, skyldtes mikroorganismer som ble overført av insekter, var det et stort fremskritt.

Av sykdommer som europeerne kunne bli utsatt for i Kongo, synes malaria og dysenteri å ha vært de hyppigste dødsårsakene. Kronisk malaria kunne føre til døden flere år etter hjemkomsten (7). Som Godøy formulerer det: Kongo levde bokstavelig talt inne i de hjemvendte kolonistene, gjennom malariaparasitten. Mange måtte leve livet ut med tilbakevendende feberanfall med svettetokter og frysninger, ledsaget av groteske fantasiinntrykk (2).

I den fiktive, men faktabaserte og delvis selvbiografiske romanen Mørkets hjerte, forteller Joseph Conrad (1857-1924) om legeundersøkelsen av Marlow, Conrads alter ego, før han reiste til Kongo for å være flodskipper (24). Legen spør om han kan få måle Marlows hode, for i vitenskapens navn ba han alltid om å få måle kraniene på dem som reiste ut. «Og når de kommer tilbake?» spurte Marlow. «Å, da ser jeg dem aldri, og dessuten skjer forandringene på innsiden, vet De.»

For kongofarerne kunne hjemkomsten være vanskelig. Erfaringene deres fra Afrika ble ikke verdsatt, de hadde problemer med å få jobb, og holdningene og personligheten de hadde utviklet i Kongo, viste seg lite gangbare i det norske samfunnet. «Tilværelsen i Kongostaten tærte på skandinavene. Alkohol, sykdom, kamerater som stadig døde, utrivelige belgiere; det fantes nok av ting som gjorde livet vanskelig for dem» (2). Legene kom imidlertid fort i gang med medisinsk virksomhet etter hjemkomsten, unntatt Heiberg som var syk og døde kort etter.

\section{Sovesykeepidemi og helsevesen}

De medisinske aktivitetene i Kongofristaten var diffuse. Det manglet både ressurser og personell. Mangel på interesse for helseproblemer burde ikke forbause i en stat som først og fremst var opptatt av finansiell virksomhet (25). I 1905, etter 20 år, hadde Kongofristaten bare omtrent 30 leger. 


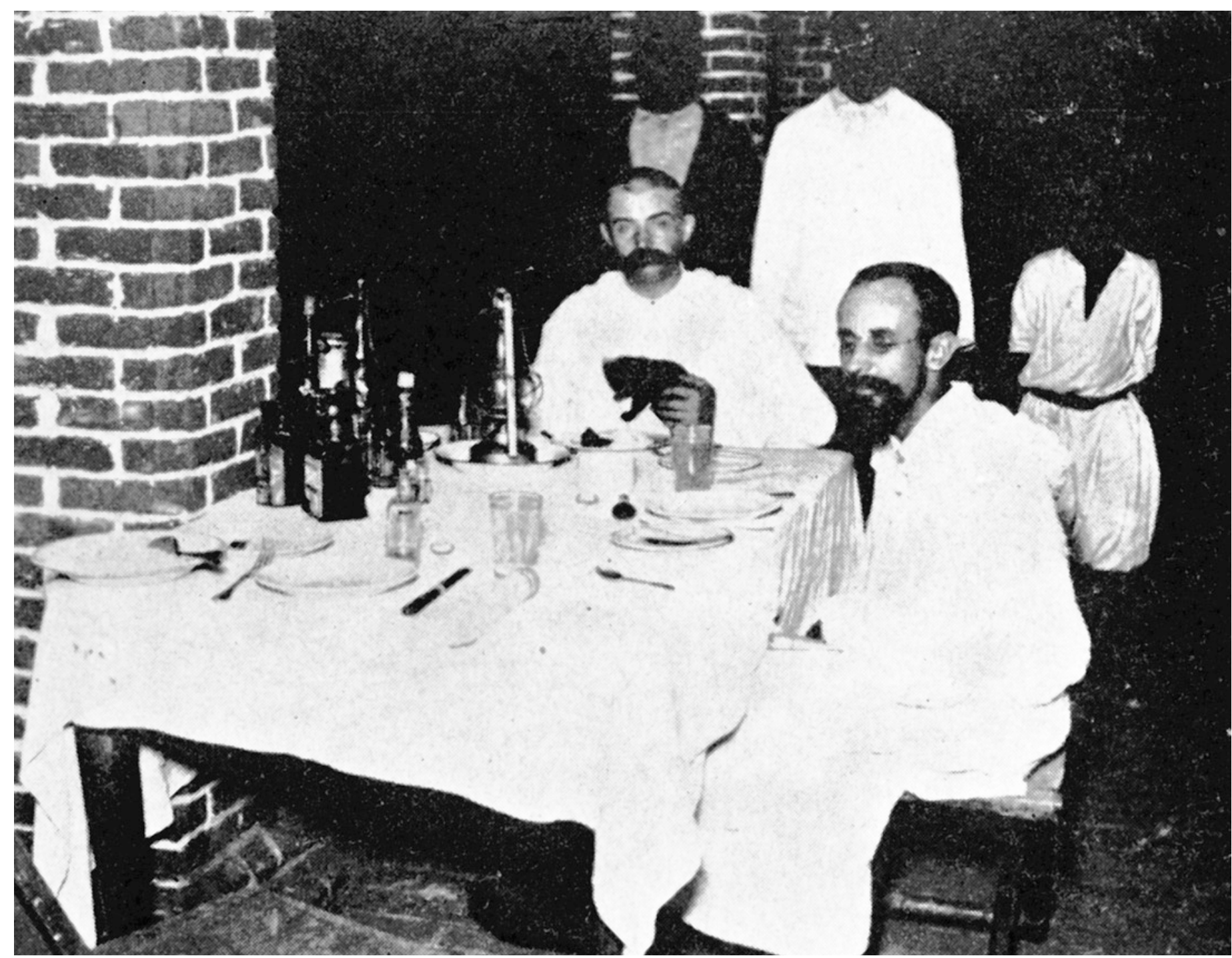

Heiberg (til venstre) og Dutton i Kasongo i januar 1905. Fotografi av figur 5 i litteraturreferanse nr. 26, mottatt fra biblioteket, Institute of Tropical Medicin, Antwerpen

I tillegg til statens leger var noen ansatt i private selskaper og innen kristen misjon. I hele kolonien var det i 1910 bare 41 leger (1). Et helsevesen eksisterte knapt på papiret og var mest innrettet for statens interesser og de fåtallige hvite kolonistene.

Kampen mot sovesyke ble imidlertid en spesiell virksomhet. De sosiale og økonomiske sidene ved sykdommen, i tillegg til de medisinske, har historikeren Maryinez Lyons gjort rede for i avhandlingen The Colonial Disease (23).

I Kongofristaten og Øst-Afrika raste en stor sovesykeepidemi mellom 1896 og 1906 med kanskje 300000 døde i fristaten og 500000 i Uganda og Kenya. Epidemien blir av de fleste forklart med migrasjonen av infiserte personer til sykdomsfrie områder, påtvunget av kolonimakten. Kongoelven med bifloder i Øvre Kongo var hovedferdselsåren, trafikkert av små dampbåter, hovedsakelig ført av skandinaviske sjøfolk. Epidemien spredte seg imidlertid også langs karavaneveiene. Kongofristaten hadde ingen klare grenser og heller ikke en homogen befolkning. Det var mange etnisiteter, språk og dialekter. De innfødte levde i mindre områder og ernærte seg gjennom landbruk, noe husdyrhold, fiske langs elvene, tradisjonelt håndverk og handel med de nærmeste lokalsamfunnene. Brutale stammekriger forekom. Under koloniseringen av fristaten med tvangsarbeid og tvangsflytting av mannlig arbeidskraft oppsto det store forandringer i lokale samfunnsstrukturer. Brudd på den tradisjonelle levemåten gikk særlig ut over matproduksjonen, noe som førte til underernæring og svekket helse (23).

Av økonomiske grunner ble det viktig å stoppe epidemien. En demografisk krise ville medføre mangel på arbeidskraft til å samle kautsjuk. Men i Øst-Afrika, hvor kvegdrift var en levevei av stor økonomisk betydning for bøndene, ble dyresovesyken viktigere å bekjempe enn den humane.

Etter en henvendelse fra kong Leopold til Liverpool School of Tropical Medicine ble det i 1903 sendt en ekspedisjon med betydelig finansiell støtte fra kongen for å studere sanitære forhold, sovesyke og andre tropiske sykdommer i Kongo. Det var blitt påvist trypanosomer for første gang i blod bare to år tidligere, i 1901. I 1902 ble det fastslått at parasitten var en protozo som fikk navnet Trypanosoma gambiense (nå T. brucei gambiense). Samme år ble den påvist i cerebrospinalvæske, og i 1903 ble det bevist at den ble overført av tsetsefluen. Forskere ved ekspedisjonen var John Everett Dutton (1874-1905) og John Lancelot Todd (18761949). Cuthbert Christy (1863-1932) deltok en tid. Ekspedisjonen gikk i land i Boma 23. september. Heiberg, som de kjente fra kurset i tropemedisin, var avgitt for å hjelpe ekspedisjonen og fulgte den fra ankomst til den ble avsluttet i 1905 (23, 26).

Man studerte også «tick fever» som liknet på den europeiske tilbakefallsfeberen som skyldes spiroketen Borrelia recurrentis med lus som vektor, Pediculus humanus corporis. I Kongo fant de at den afrikanske varianten av sykdommen skyldtes en annen spiroket, Borrelia duttoni, og at vektor var en flått, Ornithodorus moubata. Dutton og Todd fikk begge tilbakefallsfeber. Todd overlevde, men Dutton døde 29 år gammel 27.2. 1905 i Kasongo og ble begravet der $(26,27)$. 


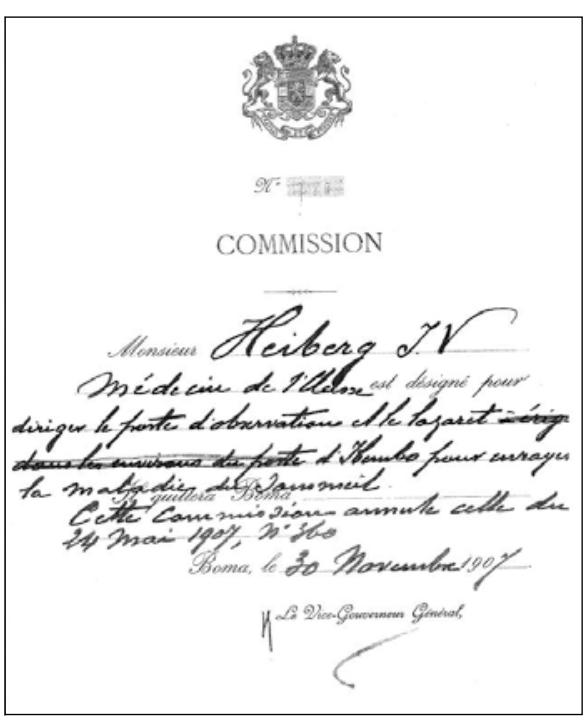

Beordringen av Heiberg til å lede observasjonsposten og lasarettet i lbembo for å bekjempe sovesyke

Ekspedisjonens hovedinteresse ble trypanosomiasis (afrikansk sovesyke). Ved human sovesyke henger tre faktorer sammen: mennesket, parasitten og tsetsefluen. Vektoren var det lite å gjøre med på den tiden, men man ryddet vegetasjon på anløpsstedene for dampbåtene og rundt stasjonene for å redusere tsetsefluens livsbetingelser. Man hadde ingen god behandling mot parasitten, men man kunne hindre at infiserte individer blandet seg med friske. De viktigste funnene og tiltakene ble beskrevet som at lymfeknuteforstørrelse var et meget konstant fenomen ved human trypanosomiasis. Parasitten kunne lett påvises $i$ aspirat fra punkterte knuter, og $i$ et infisert område ville alle med hovne lymfeknuter sannsynligvis ha sykdommen.

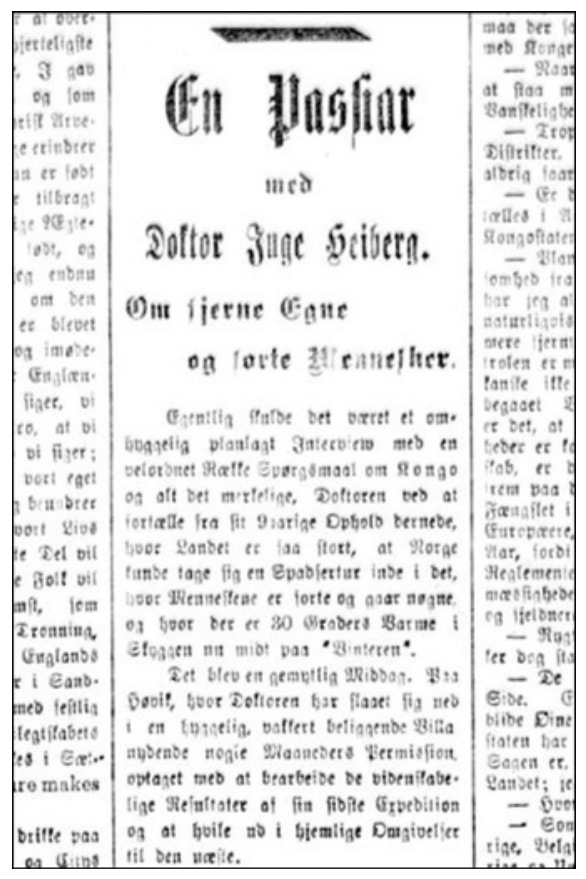

En passiar med Doktor Heiberg. Aftenposten nr. 681 18.11. 1906
Enhver innfødt med hovne knuter skulle derfor betraktes som syk inntil det motsatte var bevist. Videre mente de at det burde opprettes et karantenesystem som hindret en infisert innfødt $i$ å reise til et distrikt der sykdommen ikke fantes (28).

Dutton, Todd og Tobey fant en ny parasitt i tarmen på tsetsefluer som kunne tilhøre Myxosporidia. For å hedre samarbeidet med Heiberg og spesielt hans observasjoner av T. loricatum som de nesten alltid fant hos infisert frosk, ga de den nye parasitten navnet Myxosporidium heibergi (29). I et biografisk leksikon står det at Heiberg etter sin død ble hedret av Jérôme Rodhain (18761956) ved at han ga navnet heibergi til en trypanosom som han hadde funnet hos flaggermus (30). Men oppdageren skrev Heibergs navn feil slik at parasittens vitenskapelige navn er Trypanosoma heybergi (31).

\section{Behandling av sovesyken}

Men hvordan skulle sovesyke behandles? I 1904 ble det meldt at arsenpreparatet Atoxyl kunne helbrede infiserte dyr. Selv om det viste seg at preparatet bare virket i tidlige stadier med rikelig parasitter i blodet, kunne man i sen fase av sykdommen få noe virkning i kombinasjon med antimonpreparatet Emetique, sublimat, stryknin eller natriumjodid. På denne tid var Tyskland kolonimakt i Øst-Afrika, og spredningen av sovesykeepidemien fra Uganda ga grunn til bekymring, særlig dyresykdommen som hadde betydning for det økonomiske utbyttet av kvegdrift. Robert Koch (1843-1910) ble da leder for en ekspedisjon til Øst-Afrika i 1906-07. Dels skulle man gjøre epidemiologiske undersøkelser, dels prøve ut medikamenter, inkludert Atoxyl. Behandlingen med dette medikamentet var i begynnelsen meget lovende. Etter forsøk på mennesker viste det seg imidlertid at medikamentet hadde alvorlige bivirkninger, inkludert blindhet (32), noe som tilsa at preparatet ikke var egnet for terapeutiske formål. Atoxyl i mindre doser ga imidlertid trypanosomfritt blod i månedsvis, og dermed var den syke ikke smitteførende ved tsetsestikk. Det kunne ifølge Koch utnyttes epidemiologisk (33).

Cammermeyer rapporterte gode behandlingsresultater fra sykehuset i Boma med en blanding av Atoxyl, sublimat og natriumjodid, som han kalte Satoxyl, og som syntes å være etter egen oppskrift. Bakgrunnen for dette kombinasjonspreparatet kan ha vært positive erfaringer med sublimat og natriumjodid i sent stadium av syfilis, men også en eksperimentell undersøkelse som viste gode resultater med sublimat i sent stadium på rotter (34). Han redegjorde for sine funn etter å ha brukt preparatet på 800 pasienter fra februar 1908 til og med første halvår 1911 (35, 36, 37). Dødeligheten som i 1904 var $100 \%$, var etter første halvår i 1911 falt til $14 \%$ med denne behandlingen. Blindhet hadde han ikke observert. Men da Cammermeyer på seks pasienter prøvde Soamine, med samme virkestoff som Atoxyl, ble to av pasientene blinde $(38,39)$. Etter behandlingen var begge uten påvisbare parasitter, den ene etter full kur, den andre etter seponering midtveis i behandlingen. Den anbefalte doseringen kunne ha vært for høy mente Cammermeyer, men han kommenterte ikke Kochs resonnement.

I Heibergs rulleblad fra kongotiden er det notert at han særlig hadde beskjeftiget seg med forskning på sovesyken. Dette er også temaet $\mathrm{i}$ et intervju som ble gjort med Heiberg da han var hjemme på permisjon i 1906 (40): «Doktor Heibergs Bolig er ogsaa Laboratorium. I tallrige Reagensrør ligger en Sort Flue. Det er den farlige Tsetseflue, det Insekt, der i Regelen gjør Tjeneste som den forfærdelige Tropesygdom Sovesygens Smittebringer.» Heiberg fortalte at han hadde gjort studiet av denne sykdommen til sin spesialitet og at hans siste ekspedisjon var viet disse studiene. Videre fortalte han at han hadde organisert et stort hospital i Leopoldville for pasienter med sovesyke og at han arbeidet på et forslag til forholdsregler for å hindre at sykdommen spredte seg til områder som ikke var infisert. Historikeren Maryinez Lyons viser til flere rapporter som Heiberg sendte myndighetene (23). En av disse rapportene, der han foreslo en rekke tiltak, er datert 18. 2. 1907. Hovedpunktene var at arbeidskraft ikke måtte rekrutteres fra infiserte distrikter, at en rekke kontrollposter burde opprettes der migrerende afrikanerne måtte passere, «som gjennom en sil». Mobile enheter skulle rydde reservoarene for parasitter og insekter. Dette var i overensstemmelse med rådene fra Dutton og Todd. I Leopoldville ble det utarbeidet et reglement med anbefalinger $(23,37)$. En cordon sanitaire, en kjede av kontrollposter, ble opprettet for å hindre spredning. Særlig viktig var dette i de nordøstlige distriktene.

Heiberg ble 30.11. 1907 beordret til direktør for lasarettet ved kontrollposten i Ibembo ved bifloden Itimbiri «for å sette en stopper for sovesyken». Etter avløsning gikk han om bord i SS Albertville 26.4. $1910 \mathrm{og}$ dro til Belgia for formelt å avslutte sin tredje termin. Han vendte imidlertid tilbake i desember og ble 28.1. 1911 utnevnt til medisinaldirektør for hele Belgisk Kongo.

\section{Lasarettet Ibembo}

Lasarettet $\mathrm{i}$ Ibembo åpnet i mai 1907. Det lå ved «inngangsporten» til det økonomisk viktige Uele i den nordøstlige delen av Kongo og skulle hindre spredning til disse områdene, som man antok var fri for sykdom, bortsett fra i få og små endemiske foci. Ibembo hadde vært utgangspunktet for militære ekspedisjoner inn i Uele og hadde fra 1907 en viktig militær treningsleir. Alle båter, kanoer og karavaner skulle stoppes og undersøkes, og ingen måtte reise videre uten å ha snakket med legen. Lasarettet var 
ansett som det viktigste i regionens kjede av kontrollposter.

Langs ferdselsrutene skulle alle kontrolleres og suspekte undersøkes nøye. Ved påvist sykdom måtte man avgjøre om vedkommende skulle sendes ut av territoriet eller legges inn på lasarettet. De innlagte skulle behandles med Atoxyl og isoleres, i varierende grad fra isolat til å være under lempelig oppsyn. Kontakt med familien kunne bli nektet. Friske og syke ektefeller kunne også bli nektet samvær. Å bli innlagt ble oppfattet som livsvarig fengselsstraff. Mange av de innlagte med korrekt diagnose følte seg helt friske. Behandlingen hadde liten effekt, og etter hvert ble sykdommen symptomatisk og førte til at pasientene døde. Dette ble av pasientene oppfattet slik at det var selve oppholdet som gjorde dem syke. Vestlig medisins karantene, permanent isolering og andre tiltak ble av kongoleserne oppfattet som en del av kolonimaktens undertrykkende regime. Tiltakene hadde heller ikke den ønskede epidemiologiske virkningen. Mellom mars 1907 og mars 1909 døde $33 \%$ av de isolerte pasientene, og $6 \%$ rømte. Frustrasjonen hos de innlagte ga seg uttrykk i flere opprør i 1909 og 1910. Vaktstyrken måtte forsterkes. Heiberg skrev $i$ en rapport at lasarettet nærmest var et permanent fengsel som burde ha inskripsjonen «Ved inngang her la alt håp fare» (23).

I Belgisk Kongo ble det i 1910 også innført et system som innebar at innfødte ikke kunne forlate sitt oppholdssted mer enn $30 \mathrm{~km}$ uten et medisinsk pass, undertegnet av lege som erklærte at vedkommende ikke hadde trypanosomiasis (23).

I 1912 ble det oppdaget at sykdommen i alarmerende høy grad var utbredt også i Uele-distriktet, som er hovedtemaet i Lyons avhandling. I 1920-årene fikk man bedre medikamenter, i tillegg til at helsevesenet ble styrket og de sosiale forholdene bedret. Resultatet var at sykdommen begynte å gå tilbake. Men som ved tilbakegangen av tuberkulose $\mathrm{i}$ vår del av verden, mener mange i ettertid at fremgangen like mye skyldtes bedre sosiale forhold som medisinske tiltak. I 2009 ble det på verdensbasis meldt 9878 tilfeller, og i 2010 var det en nedgang til 7 139, noe som er de laveste tallene de siste 50 årene $(41,42)$. Blant 36 endemiske land er forekomsten størst i den demokratiske republikken Kongo (DR Kongo). I vårt land er trypanosomiasis en importert sjeldenhet (43).

\section{Kongofristatens opphør}

Kong Leopolds grove utbytting og vanstyre førte til internasjonale reaksjoner. I intervjuet i Aftenposten i 1906 avviste Heiberg den voksende kritikken av forholdene i fristaten som overdrevne rykter. Å gi inntrykk av at situasjonen var tilfredsstillende og å trekke et slør over de faktiske forholdene var ofte regelen (25). Men etter utenlandsk press måtte kongen i 1908 overlate kolonien til den belgiske staten, som opprinnelig ikke var interessert i å være kolonimakt. Deretter ble forholdene gradvis bedre. Norske leger har senere virket i Belgisk Kongo, og etter frigjøringen i 1960 var flere der i FN-tjeneste.

Jeg takker Bjørn Godøy for råd, Espen Wæhle for nyttige adresser i Bruxelles, Afrika-arkivet i det belgiske utenriksdepartementet for opplysninger fra Heibergs rulleblad, bibliotekar Dirk Schooenbaert ved Institute of Tropical Medicine Antwerpen som fant beskrivelsen av T. heybergi, arkivarer og bibliotekarer ved Liverpool School of Tropical Medicine, Bernhard-Nocht-Institut für Tropenmedizin i Hamburg, Royal Society of Tropical Medicine i London, Musée McCord Museum i Montreal, The Wellcome Trust i London og Arendal bibliotek for mye hjelp.

\section{Aksel Ongre (f. 1934)}

er tidligere overlege og spesialist i radiologi. Han er nå pensjonist og interesserer seg for medisinsk historie fra nyere tid og har skrevet flere artikler.

Forfatter har fylt ut ICMJE-skjemaet og oppgir ingen interessekonflikter.

\section{Litteratur}

1. Wæhle E. Deres drømmer ble til mareritt - skjebnetunge år med skandinavene i Kongo. I: Knudsen AV (red.). Bornholm - CONGO - tur/retur. Rønne: Bornholms museum, 2003: 81-94.

2. Godøy B. Solskinn og død. Nordmenn i kong Leopolds Kongo. Oslo: Spartacus, 2010.

3. Morel ED. Kongelig slaveleir. Historien om et terrorregime. Tillegg av Syphilia Morgenstierne om kong Leopolds norske kongofarere. 2. utg. Brandbu: Fritt og vilt, 2007

4. Hochschild A. Kong Leopolds arv. En beretning om grådighet, forferdelser og heroisme i det koloniale Afrika. Oslo: Pax, 2005

5. Reybrouk DV. Kongo. Historien om Afrikas hjerte. Oslo: Font, 2011.

6. Kongelig slaveleir. Historien om et terrorregime. www.frittogvilt.no/kongeligslaveleir/norske.html (30.5.2012).

7. Ongre A. To fra Bjarkøy i Kongofristaten og Belgisk Kongo. I: Furu E, Storvik W (red.). Årbok for Bjarkøy 2010. Bjarkøy Slekts- og Historielag, 2010: 81-4

8. Larsen $\emptyset$. (red.). Norges leger. Oslo: Den norske lægeforening, 1996; bd. 5: 321-2.

9. Larsen $\emptyset$. (red.) Norges leger. Oslo: Den norske lægeforening, 1996; bd. 2: 592-3

10. Dedichen HA. Inge Heiberg. Nekrolog. Tidsskr Nor Lægeforen 1920; 40: 502-4.

11. Wæhle E. Monganga Makazzi, Judchi og andre nordmenn under Kongostjernen 1885-1918. I: Alsaker K, Bang AK (red.). Nordmenn i Afrika afrikanere i Norge. Bergen: Vigmostad \& Bjørke, 2002

12. Wæhle E. Inge Heiberg: un médecin norvégien au Congo et la lutte contre la maladie du sommeil. I: Vellut J-L (dir.). La mémoire du Congo - le temps colonial. Tervuren: Musée Royale de l'Africe centrale, 2005: 232-234.

13. Berge 0 . Spredte erindringer fra Congo. I: Larsen $\varnothing$ (red.) Norges leger. Oslo: Den norske lægeforening, 1996; bd. 1: 268-70.

14. Larsen $\emptyset$. (red.). Norges leger. Oslo: Den norske lægeforening, 1996; bd. 1: 552-3

15. Larsen $\varnothing$. (red.). Norges leger. Oslo: Den norske lægeforening, 1996; bd. 2: 416-7

16. Aftenposten Aften 2.5. 1903.

17. Liverpool School of Tropical Medicine. Register TM/13/11/1/1, No. 63 Inge Heiberg.
18. Probst HB. En myg og en flue - historien om at være Monganga i Congo. I: Knudsen AV. Bornholm - Congo - tur/retur. Rønne: Bornholms museum, 2003: 211-23.

19. Kjerland AK, Bang AK. (red.). Nordmenn i Afrika Afrikanere i Norge. Bergen: Vigmostad \& Bjørke, 2002: 187-8

20. Lasson B. Slik var det den gang. Oslo: Gyldendal, 1938: $165-6$

21. Søegaard PM. Oberstløitnant Søegaard JenssenTusch: Skandinaver i Congo. Anmeldelse. Morgenbladet, Aftennummer, 8.4. 1905

22. Jenssen-Tusch H. Skandinaver i Congo. Svenske, norske og danske mænds og kvinders virksomhed i Den uafhengige Congostat. Kjøbenhavn: Gyldendal Boghandel - Nordisk Forlag, 1902-1905.

23. Lyons M. The colonial disease. A history of sleeping sickness in Northern Zaire, 1900-1940. Cambridge: Cambridge University Press, 1992

24. Conrad J. Mørkets hjerte. Oslo: Kagge Forlag, 2003: 27

25. Vellut J-L. European medicine in the Congo Free State. I: Janssens PG. Kivits M. Vuylsteke J. (dirs.). Analecta de réalisations médicales en Afrique centrale, 1885-1985. Fondation roi Baudouin, Masson-Paris - Peeters-Louvain, 1992: 62-81.

26. Lechat MF. L'expedition Dutton-Todd au Congo (1903-1905). Ann Soc Belg Med Trop 1964; 44: 493-512.

27. Anonym. Joseph Everett Dutton. Obituary. BMJ 1905; $1: 1020-1$

28. Todd JL. The prevention of sleeping sickness. BM 1908: 2: 1061-3.

29. Dutton JE, Todd JL, Tobey EN. Concerning certain parasitic protozoa observed in Africa. Ann Trop Med Parasitol 1907; 1: 285-370.

30. Dubois A. Heiberg (Inge-Valdemar). Biographie coloniale belge. Bruxelles: Institut royal colonial belge, 1951; 2: 463

31. Rodhain J. Trypanosome d'un Cheiroptère insecti vore Nycteris hispida Schreber au Congo belge. Bulletins de la Société de Pathologie Exotique, Tome XVI. Paris: Masson \& Cie, 1923: 659-663.

32. Steverding D. The development of drugs for the treatment of sleeping sickness: a historical review. Parasites \& Vectors 2010; 3. www . parasitesandvectors.com/content/3/1/15 (30.5. 2012).

33. Gradmann C. Laboratory Disease: Robert Koch's Medical Bacteriology. Baltimore: Johns Hopkins, 2009: $201-229$

34. Moore B, Nierenstein M, Todd JL. On the treatment of trypanosomiasis by Atoxyl (followed by a mercury salt). Biochem J 1907; 2: 300-24.

35. Cammermeyer J. Traitement de la maladie du sommeil, pendant l'année 1908, par la méthode Atoxyl-Mercure-lodure. Norsk Mag Lægevidensk 1910; 71: 76-8

36. Cammermeyer J. Discussion. Proceedings of a Meeting of the Society on Friday, October $20^{\text {th }}$ 1911. Transactions of the Society of Tropical Medicine and Hygiene 1911; 5: 26-7.

37. Cammermeyer J. Om trypanose. Norsk Mag Lægevidensk 1912; 73: 98-103.

38. Cammermeyer J. Notes de pratique médicale africaine. Archiv für Schiffs- und Tropen-hygiene 1912; 16: 84-6.

39. Moore B. Atoxyl and Soamin and the treatment of sleeping sickness and syphilis. BMJ 1909; 6: 370 -1. http://ukpmc.ac.uk/articles/PMC2318099/ ?page $=1(30.5 .2012)$

40. En passiar med Doktor Heiberg. Aftenposten nr. 681, 18.11. 1906

41. WHO. African trypanosomiasis (sleeping sleek ness). Fact sheet NJ 259 October 2010 www.who.int/mediacentre/factsheets/fs259/en/ (30.5.2012)

42. WHO. New cases of African trypanosomiasis continue to drop. www.who.int/neglected diseases/ disease_management/HAT_cases_drop/en/ index.html (30.5.2012)

43. Myrvang B, von der Lippe B. Afrikansk trypanosomiasis - en sjelden importsykdom. Tidsskr Nor Lægeforen 2002; 122: 33-4.

Mottatt 23.9. 2011, første revisjon innsendt 19.3. 2012, godkjent 31.5. 2012. Medisinsk redaktør Anne Kveim Lie. 